\title{
SURFACE RUNOFF OF RAINFALL IN AN EXPERIMENTAL PLANTATION OF MACAÚBA PALM (Acrocomia aculeata) UNDER DIFFERENT FORMS OF MANAGEMENT ${ }^{1}$
}

João Batista Lúcio Corrêa ${ }^{2}$, Herly Carlos Teixeira Dias ${ }^{3 *}$, Kelly Cristina Tonello ${ }^{4}$, Valdir de Cicco ${ }^{5}$, Elias Silva $^{3}$, Lucas Jesus da Silveira ${ }^{6}$ and Aurora Yoshiko Sato ${ }^{7}$

\footnotetext{
${ }^{1}$ Received on 29.06.2015 accepted for publication on 25.10.2017.

${ }^{2}$ Universidade Federal de Viçosa, Graduado em Engenharia Florestal, Viçosa, Minas Gerais - Brasil. E-mail: $<$ batistacefetrp@yahoo.com.br>.

${ }^{3}$ Universidade Federal de Viçosa, Departamento de Engenharia Florestal, Viçosa, Minas Gerais - Brasil. E-mail: $<$ herlycarlostdias@gmail.com> and <eshamir@ufv.br>.

${ }^{4}$ Universidade Federal de São Carlos, Departamento de Ciências Ambientais, Sorocaba, São Paulo, Brasil. E-mail: $<$ kellytonello@yahoo.com>.

${ }^{5}$ Instituto Florestal do Estado de São Paulo, SP - Brasil. E-mail: <valdircicco@if.sp.gov.br>.

${ }^{6}$ Universidade Federal de Viçosa, Mestre em Ciências Florestais, Viçosa, Minas Gerais - Brasil. E-mail: <ljsfloresta@hotmail.com>.

${ }^{7}$ Universidade Federal de Viçosa, Laboratório de Anatomia Vegetal, Viçosa, Minas Gerais - Brasil. E-mail: <aurorasato@gmail.com>.

*Corresponding author.
}

\begin{abstract}
Several studies have been conducted aiming to explore the commercial potential of the macaúba palm. However, research on the hydrological processes of this crop are scarce. Thus, we aimed to quantify the surface runoff in a macaúba plantation subjected to different crop management techniques, from September 2012 to August 2013. We established 10 plots for surface runoff quantification; each plot had a $63-\mathrm{m}^{2}$ area, was delimited by metallic foils and had a gallon to collect runoff water at its outlet. Plots consisted of three treatments and three repetitions, plus one control plot, each having four macaúba plants. Treatments were as follows: treatment one (T1) - with no soil conservation technique being implemented; treatment two (T2) - with a narrow-base terrace $40 \mathrm{~cm}$ wide and $30 \mathrm{~cm}$ deep; treatment three (T3) - with bean being planted during the rainy months, forming vegetation strips; and control treatment (T0) - with no macaúba plants, with spontaneous vegetation growing throughout the entire plot and with no soil conservation technique being implemented. Surface runoff differed among treatments. T2 was the treatment with lowest runoff and also the one that demanded the highest precipitation volume for surface runoff to occur. Our results indicate that both the cover and the use of soil conservation techniques are closely related to surface runoff, which in turn affects the occurrence of erosion and infiltration.
\end{abstract}

Keywords: Forest hydrology; Soil erosion; Infiltration.

\section{ESCOAMENTO SUPERFICIAL DE AGUA DE CHUVA EM PLANTIO EXPERIMENTAL DE MACAÚBA (Acrocomia aculeata), SOB DIFERENTES FORMAS DE MANEJO}

RESUMO-Diversos estudos têm sido conduzidos com o objetivo de se conhecer as potencialidades comerciais da macaúba. Contudo, há escassez de estudos sobre os processos hidrológicos dessa cultura. Assim, este estudo teve por objetivo quantificar o escoamento superficial no plantio de macaúba, sob influência de diferentes técnicas de manejo da cultura, no periodo de setembro de 2012 até agosto de 2013. Foram instaladas dez parcelas de quantificação do escoamento superficial com área $63 \mathrm{~m}^{2}$ cada, delimitadas com lâminas metálicas e, na saída de cada parcela, galões para coleta da água de escoamento. As parcelas constituíram três tratamentos com três repetições, e parcela testemunha, cada uma envolvendo quatro (4) plantas de macaúba. No tratamento um (T1) sem técnicas de conservação do solo; o tratamento dois (T2): cordão de contorno com 40 cm centímetros de largura por $30 \mathrm{~cm}$ de profundidade; o tratamento três (T3): durante os meses chuvosos com plantio de feijão em faixas; o tratamento testemunha (T0): sem plantas de macaúba, com a vegetação espontânea crescendo por toda a parcela, onde não foi usada nenhuma técnica de conservação de solo. O escoamento superficial se comportou de maneira diferente entre os tratamentos. T2 apresentou menores valores de escoamento superficial, sendo, também, o tratamento 
no qual o escoamento superficial exigiu maior volume de precipitação para que se iniciasse. Os resultados indicam que tanto a cobertura como o uso de técnicas de conservação do solo estão intimamente relacionadas com o processo de escoamento superficial, que por sua vez, terá influência em processos erosivos e à infiltração.

Palavras-Chave: Hidrologia florestal, Processo erosivo e Infiltração.

\section{INTRODUCTION}

The main cause of cropland degradation is soil erosion, which consists in the displacement and carrying of particles by water and wind. In Brazil, water erosion is the most preponderant one, accounting for most soil loss in the country. Surface runoff transports suspended soil particles, nutrients, organic matter, seeds and agrochemicals, hampering agricultural production and polluting water resources (Bertoni and Lombardi Neto, 1990).

In microbasin management, several practices are usually implemented to, among other things, preserve soil and water. In that sense, protecting the soil by adopting different management techniques aims mainly to favor rainwater infiltration in the soil and to supply the water table, while also minimizing erosion by avoiding surface runoff. In regions having tropical forests, these ecosystemic services are naturally provided with high efficiency by the native plant cover. On the other hand, removal of native vegetation and the introduction of agricultural crops facilitates the occurrence of surface runoff due to the decreased soil protection therein. Thus, it is important not only to employ management practices but also to know and use plants that, besides providing a high economic yield, promote soil protection and avoid surface runoff, and consequently prevent the occurrence of soil erosion.

The macaúba (Acrocomia aculeata (Jacq.) Lodd. ex Mart.) is an oil palm native to the Brazilian flora, having an economic potential that has been highlighted in recent research (Dias et al., 2011). Several studies have indicated that the cultivated macaúba may be able to reach a yield of up to $4.8 \mathrm{tha}^{-1}$ of oil, which is equivalent to the yield obtained with the African oil palm. Currently, the African oil palm is the crop with highest yield of oil per cultivated hectare, and also the one that contributes the most to all plant oil produced worldwide. The advantage of the macaúba palm in relation to the African oil palm is its adaptability to the entire tropical zone of Latin America, while the latter is restricted to equatorial zones (Pimentel et al., 2011).
When well managed, macaúba crops may provide several benefits, such as yielding high amounts of oil for use as biodiesel, while at the same time enabling soil protection, avoiding soil erosion and conserving water quality and availability. According to Dias et al. (2011), due to its botanic and morphological features, the macaúba palm favors efficient rainwater interception. The authors consider that the funnel-shaped crown of the species acts as a group of small gutters, which conduct the intercepted rainwater to the central region of the leaf, which in turn conducts it to the stipe. The authors also state that the presence of thorns and trichomes increases the interception surface, retain moisture and maintain the microclimatic temperature. Lastly, the authors infer that macaúba crops positively contribute with hydrologic processes, promote a higher water infiltration in the soil and reduce surface runoff.

With the present study, which was performed three years after saplings were planted, we aimed to quantify the surface runoff in an area of macaúba plantation that was implemented with different crop management techniques.

\section{MATERIALAND METHODS}

\subsection{Study area}

Data was collected at the Experimental Farm of Federal University of Viçosa (UFV), located in Araponga municipality, Minas Gerais state, southeastern Brazil.

The experimental farm is located between coordinates $20^{\circ} 40^{\prime} \mathrm{S}$ and $42^{\circ} 31^{\prime} \mathrm{W}$, at an $885-\mathrm{m}$ altitude. According to Costa and Silva (2008), climate in the region is type Cwb in Köppen's classification, being characterized as subtropical/tropical highland climate, with dry winters and hot summers. Annual temperature ranges between 3 and $28^{\circ} \mathrm{C}$ and mean annual precipitation ranges from 1300 to $1500 \mathrm{~mm}$. Soil in the region is classified as dystrophic Red-Yellow Latosol.

Saplings were one-year-old when they were transplanted to pits, with a $5 \times 5$ spacing, over an area of 1.7 ha (680 plants), in February 2009. We monitored

Revista Árvore. 2018;42(1):e420104 
gross precipitation and surface runoff in the area from September 2012 through August 2013.

\subsection{METHODOLOGY}

To monitor gross precipitation, we used three rain gauges made with PVC pipes of $14.4 \mathrm{~cm}$ in diameter and a consequent catchment area of $162.86 \mathrm{~cm}^{2}$, fixed so that the opening was positioned at $1.5 \mathrm{~m}$ aboveground. Gauges were placed in the surroundings of the planted area, distant $8 \mathrm{~m}$ from the plots in order to avoid interference from the collected volume of gross precipitation.

The rain gauges were monitored on a daily basis, and whenever there was precipitation we performed a single collection at between 7:00 and 8:00 AM. After collection, data was digitalized for posterior tabulation and analysis, which enabled the compilation of daily, monthly and annual rainfall reports.

We assessed the number of rainfall events that occurred during the study period as well as the number of surface runoff events.

To monitor surface runoff as a function of gross precipitation, and to compare the effects of different management systems on soil conservation, we established 10 plots of $63 \mathrm{~m}^{2}$, each one being delimited by $32 \mathrm{~m}$ of metallic foil (flashing), with a gutter being constructed to collect the runoff volume in 25-L gallons (Figure 1). In order to compare these measurements with the ones of gross precipitation, the volumes collected in L from the surface-runoff plots were converted to millimeters (mm), as follows:

$$
\mathrm{SR}(\mathrm{mm})=\mathrm{V}(\mathrm{L}) / \mathrm{A}\left(\mathrm{m}^{2}\right)
$$

where SR represents the surface runoff in millimeters; $\mathrm{V}$ is the volume runoff and accumulated in the gallons, in L; and A represents the area of each plot in $\mathrm{m}^{2}$.

The 10 plots consisted of three treatments and three repetitions, plus the control plot; each plot had four macaúba plants. Treatment 1 (T1) was composed of macaúba individuals planted in pits without adopting any soil conservation technique; treatment 2 (T2) was composed of individuals planted in pits and a narrowbase terrace of $40 \mathrm{~cm}$ in width and $30 \mathrm{~cm}$ in depth, located in the plot and beneath the plants; treatment three (T3) consisted in the plantation of macaúba individuals in pits and, in the rainy months, plantation of beans in vegetation strips; the control treatment (T0) was represented by a plot without macaúba plants, with spontaneous vegetation growing throughout the entire plot and no soil conservation technique being used.

In all plots from treatments $\mathrm{T} 1, \mathrm{~T} 2$ and $\mathrm{T} 3$, we cared to control the spontaneous vegetation over a $1-\mathrm{m}$ radius around the macaúba plants.

Surface runoff was compared among treatments by analysis of variance. When the analyzed values were statistically different, their means were compared by Tukey's test at $5 \%$ significance, using software SISVAR (Ferreira, 2011). We also performed a regression analysis to verify the behavior of surface runoff as a function of gross precipitation.

\section{RESULTS}

Samples were collected during 94 rainfall events from September 2012 to August 2013. The volumes recorded during the rainfall events ranged between a minimum of $2.83 \mathrm{~mm}$ and a maximum of $55.65 \mathrm{~mm}$. Gross precipitation totalized $1339.95 \mathrm{~mm}$, being representative of the local annual precipitation, which ranges between 1300 and $1500 \mathrm{~mm}$. The months with highest rainfall volume, lowest rainfall volume and no rainfall occurrence were, respectively: November 2012, August 2013 and July 2013 (Figure 2a). We observed a higher rainfall concentration in November 2012, January 2013 and March 2013, with a total rainfall volume of $833.12 \mathrm{~mm}$ in those three months, which is equivalent to $62 \%$ of the gross precipitation that occurred in the 12-month period.

The 94 rainfall events that occurred during the study period produced an average 49 surface runoff events among the treatments, which is equivalent to $52 \%$ of the rainfall events. The control treatment (T0) had the lowest number (35) of surface runoff events, which is equivalent to $37 \%$ of the precipitation events, while the highest number of events occurred at treatment 3 (T3), the one having beans planted during most of the rainy period (Table 1 ).

Among the studied treatments (T1, T2 and T3), treatment $\mathrm{T} 2$, i.e. the one with narrow-base terrace, showed the lowest number of surface runoff events (Table 1).

In May 2013, three surface runoff events took place during merely four rainfall events (75\%) (Table 1). In that month, rainfall events occurred in close days 


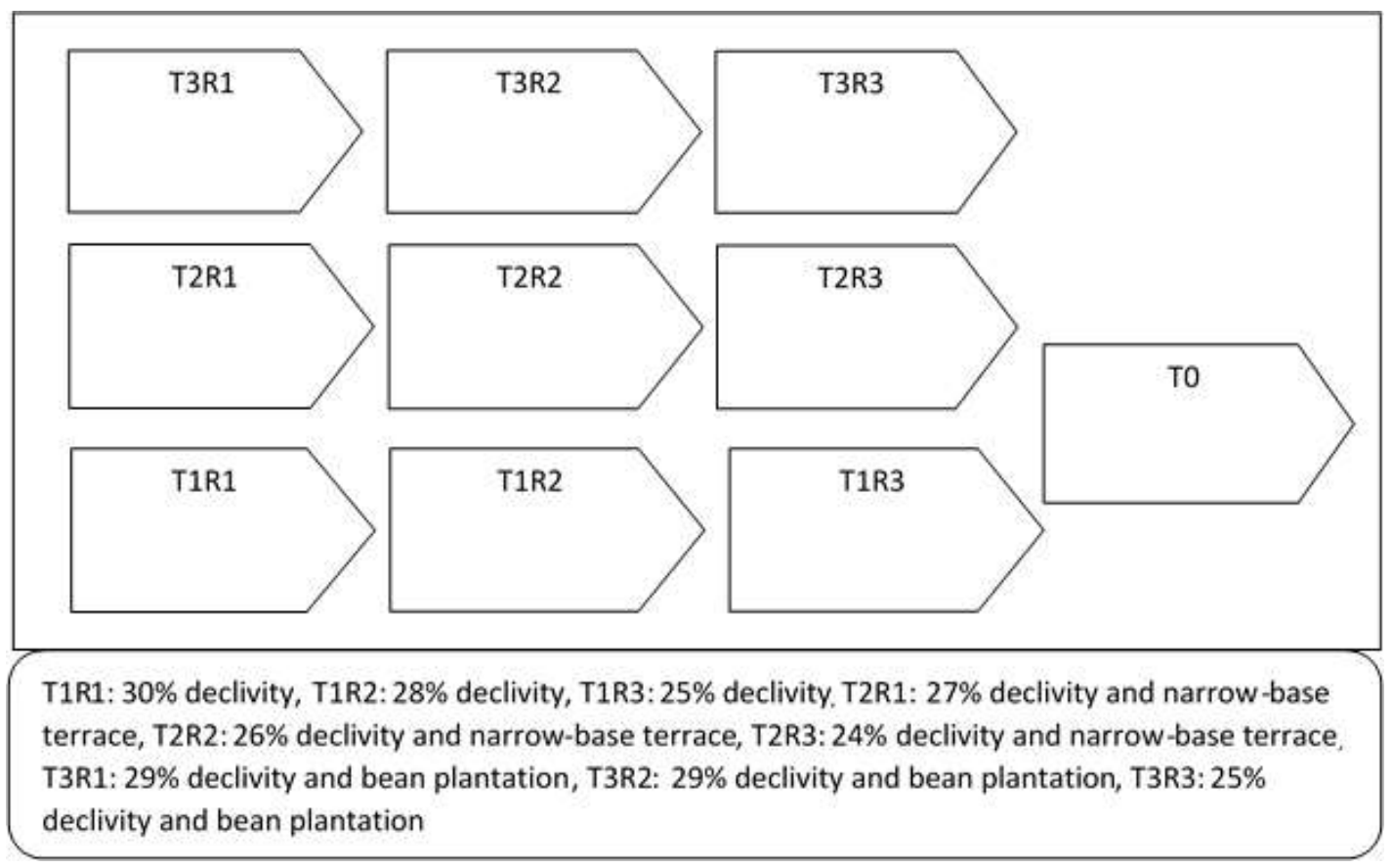

Figure 1 - Schematic representation of the surface runoff plots. $\mathrm{T}=$ treatment; $\mathrm{R}=$ replicate.

Figura 1-Representação esquemática para ilustrar as parcelas de escoamento superficial. $T=$ tratamento, $R=$ repetição.

$(23,25,28$ and 29), meaning that the soil retained a high moisture content, which thus favored the occurrence of surface runoff.

The comparison between the surface runoff volumes $(\mathrm{mm})$ at treatments $\mathrm{T} 1, \mathrm{~T} 2$ and $\mathrm{T} 3$ in each month of the study period is shown in Figure $2 \mathrm{~b}$. Treatment $\mathrm{T} 2$ (with narrow-base terrace) showed the lowest surface runoff values in all 12 months of the study period, which confirms the importance of this soil conservation technique for cultivating the macaúba palm on inclined terrains. Treatment T3 (with bean crop) showed the highest surface runoff values.

During most of the study period, the control treatment (T0), i.e. the one without macaúba plants and with no management technique, showed the lowest values of surface runoff, except in September and October 2012 (Figure 2b).

Treatment means were compared by Tukey's test at $5 \%$ probability. Treatment $\mathrm{T} 2$ showed the lowest mean monthly volumes of surface runoff in all studied months. Values recorded at $\mathrm{T} 2$ differed statistically from those recorded at T1 and T3 in October and November 2012 and in January and March 2013 (Table 2).

Revista Árvore. 2018;42(1):e420104
Treatment T2 (with narrow-base terrace) was the one that showed the lowest surface runoff volume among all treatments, during the 12 months of study. This treatment showed a runoff percentage equivalent to $0.10 \%$ of gross precipitation, followed by treatment $\mathrm{T} 1$ (with no conservation technique), with $0.21 \%$ of gross precipitation, and treatment $\mathrm{T} 3$ (with bean crop), with $0.26 \%$ of gross precipitation.

There was a positive linear correlation between gross precipitation volume and surface runoff volume at all treatments. The coefficients of determination $\left(\mathrm{R}^{2}\right)$ for treatments T1 (with no conservation technique), T2 (with narrow-base terrace) and T3 (with bean crop) were 0.484 , 0.459 and 0.404 respectively, which indicates that for the three studied treatments, $48 \%$ (T1), 46\% (T2) and 40\% (T3) of the surface runoff volumes obtained can be explained by the variable gross precipitation(Figure 4). The percentages not explained by gross precipitation are due to the influence of other variables, among which Penman (1963) highlights the rainfall intensity, rainfall duration, and the previous moisture content of the soil.

Treatment T0 (control), in which there were no macaúba plants and where spontaneous vegetation 

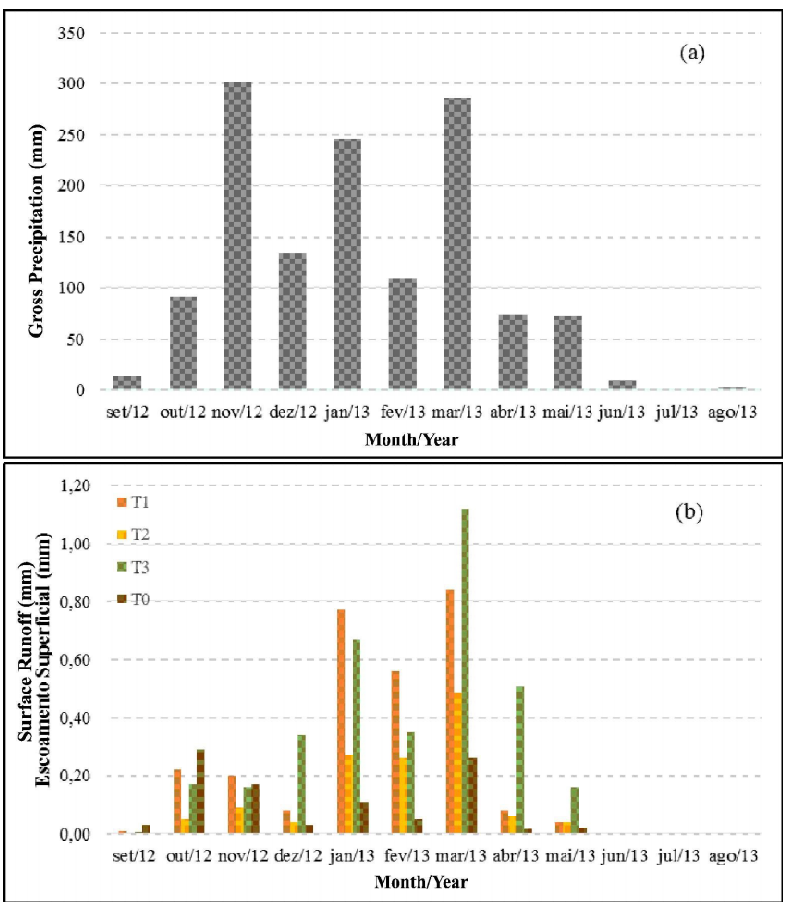

Figure 2 - Distribution of (a) Gross precipitation ( $\mathrm{mm}$ ) and (b) Surface runoff $(\mathrm{mm})$ per treatment, Experimental Farm of UFV, Araponga municipality, Minas Gerais state, southeastern Brazil. September 2012 to August 2013.

Figura 2 - Distribuição da (a) Precipitação em aberto ( $\mathrm{mm}$ ) e (b) escoamento superficial $(\mathrm{mm})$ por tratamento, Fazenda Experimental UFV, Araponga - MG. Setembro de 2012 a agosto de 2013. developed over the entire plot, showed the lowest coefficient of determination $\left(\mathrm{R}^{2}=0.259\right)$. This implies that only $26 \%$ of the surface runoff volumes obtained thereat can be explained by the variable gross precipitation, indicating a higher influence by the other aforementioned variables.

After equaling the four regression equations to zero (Figure 3), we were able to infer that surface runoff occurred at the four studied treatments after gross precipitation values were equal to or higher than: 5.73 $\mathrm{mm}$ at $\mathrm{T} 1,6.63 \mathrm{~mm}$ at $\mathrm{T} 2,3.56 \mathrm{~mm}$ at $\mathrm{T} 3$, and $7.00 \mathrm{~mm}$ at T0. We observed that the presence of a narrowbase terrace (T2) in the macaúba plantation led to a demand for higher precipitation volumes for surface runoff to occur, while plantation of beans between lines of macaúba individuals (T3) led to a demand for lower rainfall volumes for the process to occur. In the control treatment (T0), surface runoff occurred only with a rainfall volume higher than $7.0 \mathrm{~mm}$, which indicates that the spontaneous vegetation which occupied the entire plot of this treatment promoted a higher protection of soil against erosive processes caused by surface runoff.

\section{DISCUSSION}

Several authors have investigated the effects of several vegetation types on soil and water conservation, and how the different forms of vegetation can restrict soil loss and improve environmental conditions, as vegetation

Table 1 - Gross precipitation (mm and number of events) and surface runoff (number of events) at the evaluated treatments, Experimental Farm of UFV, Araponga municipality, Minas Gerais state, southeastern Brazil. September 2012 to August 2013.

Tabela 1 - Precipitação em aberto ( $m m$ e $n^{\circ}$ de eventos) e escoamento superficial ( $n^{\circ}$ de eventos) nos diversos tratamentos, Fazenda Experimental da UFV, Araponga, MG. Setembro de 2012 a agosto de 2013.

\begin{tabular}{|c|c|c|c|c|c|c|c|}
\hline \multicolumn{3}{|c|}{ Gross precipitation } & \multicolumn{5}{|c|}{ Surface runoff (no. of events) } \\
\hline Month & $(\mathrm{mm})$ & No. of events & T 1 & T2 & T3 & T0 & Mean \\
\hline Sep 12 & 13.39 & 2 & 1 & 1 & 1 & 1 & 1 \\
\hline Oct 12 & 91.28 & 6 & 2 & 2 & 2 & 2 & 2 \\
\hline Nov 12 & 301.12 & 18 & 10 & 9 & 10 & 8 & 9.25 \\
\hline Dec 12 & 133.92 & 12 & 5 & 5 & 7 & 5 & 5.5 \\
\hline Jan 13 & 246.22 & 16 & 7 & 6 & 12 & 5 & 7.5 \\
\hline Feb 13 & 108.46 & 10 & 7 & 6 & 8 & 2 & 5.75 \\
\hline Mar 13 & 285.78 & 15 & 11 & 9 & 11 & 6 & 9.25 \\
\hline Apr 13 & 74.51 & 9 & 6 & 5 & 8 & 3 & 5.5 \\
\hline May 13 & 72.25 & 4 & 3 & 3 & 3 & 3 & 3 \\
\hline Jun 13 & 9.81 & 1 & 0 & 0 & 0 & 0 & 0 \\
\hline Jul 13 & 0 & 0 & 0 & 0 & 0 & 0 & 0 \\
\hline Aug 13 & 3.21 & 1 & 0 & 0 & 0 & 0 & 0 \\
\hline Total & 1339.95 & 94 & 52 & 46 & 62 & 35 & 49 \\
\hline
\end{tabular}


Table 2 - Gross precipitation (GP) and monthly means of surface runoff (mm) in a macaúba palm (Acrocomia aculeata) plantation at the Experimental Farm of UFV, Araponga municipality, Minas Gerais state, southeastern Brazil. September 2012 to August 2013. Means followed by the same letter in a row do not differ by Tukey's test $(\mathrm{p}>0.05)$.

Tabela 2 - Precipitação em aberto e médias mensais de escoamento superficial (mm), em plantio de macaúba (Acrocomia aculeata), na Fazenda Experimental da UFV, Araponga - MG. Setembro/2012 a agosto/2013. As médias indicadas com a mesma letra nas linhas não se diferem pelo Teste Tukey $(p>0,05)$.

\begin{tabular}{lccccc}
\hline Month & GP $(\mathrm{mm})$ & T 1 & T2 & T3 & T0 \\
\hline Sep 12 & 13.39 & $0.009 \mathrm{a}$ & $0.001 \mathrm{~b}$ & $0.004 \mathrm{~b}$ & 0.030 \\
\hline Oct 12 & 91.28 & $0.220 \mathrm{a}$ & $0.050 \mathrm{~b}$ & $0.170 \mathrm{a}$ & 0.290 \\
Nov 12 & 301.12 & $0.200 \mathrm{a}$ & $0.090 \mathrm{~b}$ & $0.160 \mathrm{a}$ & 0.170 \\
Dec 12 & 133.92 & $0.080 \mathrm{a}$ & $0.040 \mathrm{a}$ & $0.340 \mathrm{~b}$ & 0.030 \\
Jan 13 & 246.22 & $0.770 \mathrm{a}$ & $0.270 \mathrm{~b}$ & $0.670 \mathrm{a}$ & 0.110 \\
Feb 13 & 108.46 & $0.560 \mathrm{a}$ & $0.260 \mathrm{~b}$ & $0.350 \mathrm{~b}$ & 0.050 \\
Mar 13 & 285.78 & $0.840 \mathrm{a}$ & $0.490 \mathrm{~b}$ & $1.120 \mathrm{a}$ & 0.260 \\
Apr 13 & 74.51 & $0.080 \mathrm{a}$ & $0.060 \mathrm{a}$ & $0.510 \mathrm{~b}$ & 0.015 \\
May 13 & 72.25 & $0.040 \mathrm{a}$ & $0.040 \mathrm{a}$ & $0.160 \mathrm{~b}$ & 0.020 \\
Jun 13 & 9.81 & 0.000 & 0.000 & 0.000 & 0.000 \\
Jul 13 & 0 & 0.000 & 0.000 & 0.000 & 0.000 \\
\hline Aug 13 & 3.21 & 0.000 & 0.000 & 0.000 & 0.000 \\
\hline
\end{tabular}

structure (canopy cover, plant density and litter height) might well be the major factor determining soil and water loss (Bochetab et al., 1999; Zang et al., 2015).

In that sense, we observed that the lowest number of events and lowest volume of surface runoff were recorded at the control treatment (T0). This may be justified by the fact that in that plot, which was devoid of macaúba plants and had no management technique implemented to control spontaneous vegetation, such vegetation grew freely and occupied the whole plot area along the entire study period, providing the soil therein with higher protection. Soil cover is a factor directly related to the processes of surface runoff and water infiltration. Regardless of the type of plant cover, surface runoff velocity decreased markedly with the increase in percentage of soil cover (Costa et al., 2013; Fernandes et al., 2013; Lorenzon et al., 2015).

At the treatment with bean cultivation (T3), spontaneous vegetation growth was cared to be controlled during the entire developmental period of the crop, which explains the occurrence of a higher number of surface runoff events at that treatment. Even in January and February 2013, when bean plants were fully developed, the surface runoff volumes at that treatment were significantly high.

At T3, which had bean plants cultivated in vegetation strips as a management practice aimed at avoiding the occurrence of surface runoff, a lower surface runoff volume was expected in relation to $\mathrm{T} 1$, in which no management technique was implemented. However, spontaneous vegetation at $\mathrm{T} 1$ covered the plots during most of the study period, thus conferring a higher protection to the soil thereat.

Furthermore, when comparing the results obtained at treatments $\mathrm{T} 3$ and $\mathrm{T} 1$, we observed that only in February 2013 was the T3 value lower than the T1 one, when the former even approached the value obtained at $\mathrm{T} 2$, where the narrow-base terrace technique was implemented. Such better result detected at T3 occurred in the month when the fully developed bean plants provided the soil with higher protection.

Lima (1988) studied the correlation between gross precipitation and surface runoff along four years in five $1000-\mathrm{m}^{2}$ plots planted with Eucalyptus grandis, the plots being equipped with flash-flood collectors, in an area of sandy soils from São Simão municipality, São Paulo state, southeastern Brazil. The author reported surface runoff values ranging from $1.7 \%$ to $3.2 \%$ of gross precipitation in the year when trees were planted. As the eucalypts grew, surface runoff decreased markedly, dropping to values that ranged around $0.5 \%$ in the fourth year.

Silva et al. (1999) evaluated the effect of soil and water loss in the intercropped plantation of beans and maize, cultivated by the following modes of soil preparation: using a hoe (Hoe), plowing and harrowing $(\mathrm{PH})$, two plowings and one harrowing $(\mathrm{PPH})$, and harrowing $(\mathrm{H})$. The study was conducted from 1970

Revista Árvore. 2018;42(1):e420104 

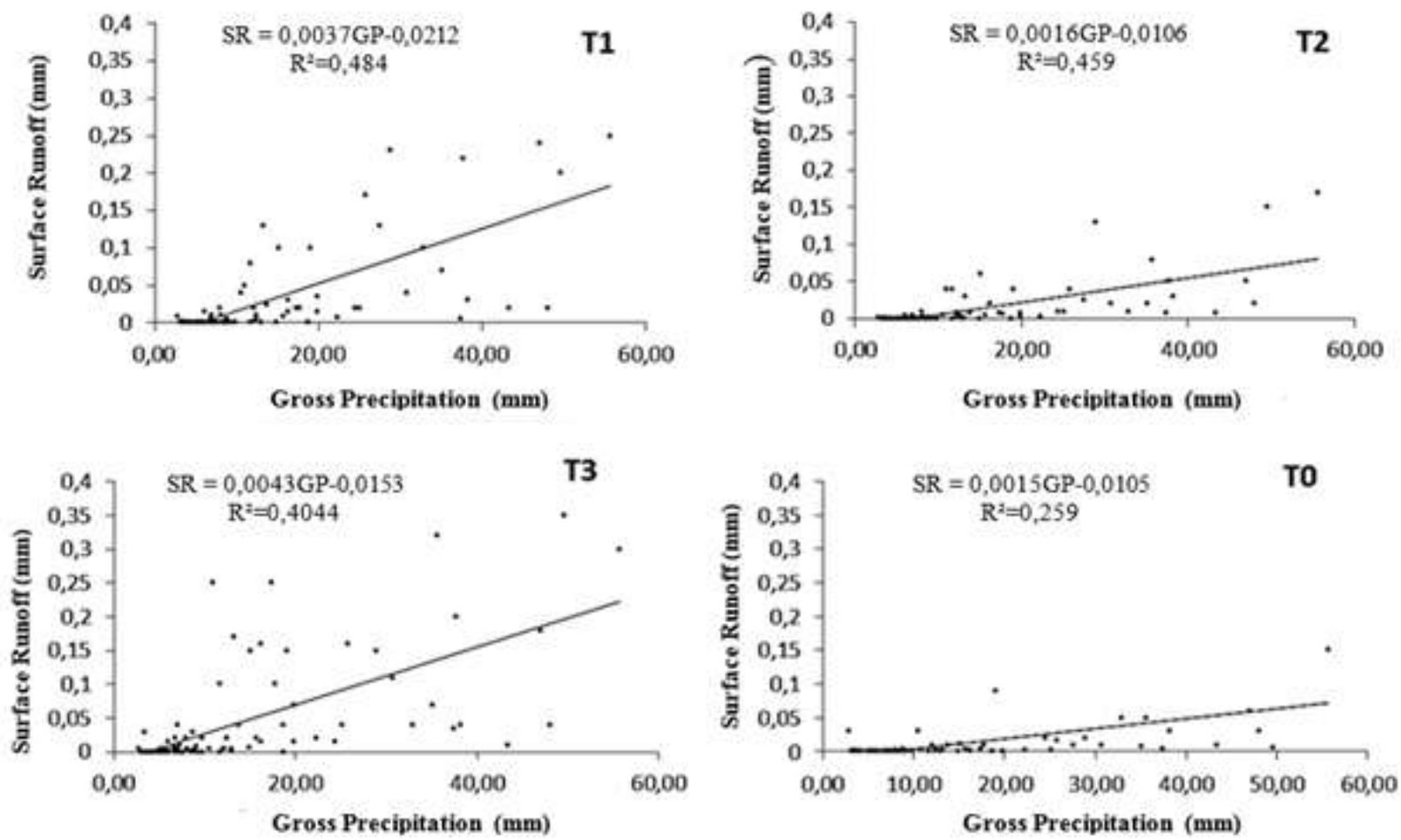

Figure 3 - Correlation between gross rainfall and surface runoff at treatments: T1 (no conservation technique), T2 (with narrow-base terrace), T3 (with bean plantation) and T0 (no macaúba plants), in a macaúba palm plantation at the Experimental Farm of UFV, Araponga municipality, Minas Gerais state, southeastern Brazil. September 2012 to August 2013

Figura 3 - Correlação entre precipitação em aberto e escoamento superficial nos tratamentos: T1 (sem técnicas de conservação), T2 (cordão de contorno), T3 (plantio de feijão) e TO (sem plantas de macaúba), em plantio de macaúba. Fazenda Experimental da UFV, Araponga - MG. Setembro de 2012 a agosto de 2013.

through 1990, in an area with eutrophic Regosol and a $12 \%$ declivity. The surface runoff values recorded were: $1.3 \%, 3.4 \%, 3.5 \%$ and $1.7 \%$ of gross precipitation at treatments Hoe, $\mathrm{PH}, \mathrm{PPH}$ and $\mathrm{H}$, respectively. In a Seasonal Semideciduous Forest fragment, Lorenzon et al. (2015) observed that surface runoff of rainwater in plots having mean declivity of $23 \%$ was equivalent to $2.08 \%$ of gross precipitation. These values allow us to infer that the results obtained at treatments with macaúba plantations on an area with a mean declivity of $25 \%$ are relatively low, and that treatment $\mathrm{T} 3$, the one with bean cultivation and that showed the highest runoff value $(0.26 \%)$ among the studied treatments with macaúba plantations, yielded a value five times lower than the lowest value obtained by Silva et al. (1999) in the beans/maize intercropping system planted on an area of lower declivity. Moreover, when comparing our data with the ones of Lorenzon et al. (2015), who conducted their research at declivities similar to the ones of our study, the surface runoff we recorded in the macaúba plantations was eight times lower.

In Shangnan County, China, El Kateb et al. (2013) performed a study aiming to determine and compare the soil loss and surface runoff in areas with five types of plant cover and at three declivity levels. The authors observed a high alteration in surface runoff among the different plant covers and declivities, yet not so pronounced as the alteration in soil loss. The results showed that the higher the declivity, the higher the potential for occurrence of surface runoff and soil loss. In addition, the erosion rate was substantially affected by changes in the plant cover. Croplands yielded the highest surface runoff and soil loss, while tea plantations at declivities higher than $30^{\circ}$ were more susceptible to erosion. Herb plantations showed less runoff and soil loss than croplands. Forest areas provided evidence 
of their importance for soil and water conservation in the study site, since, according to the authors, soil losses in those areas were negligible compared to areas with the other plant covers.

Silva et al. (1990) evaluated the surface runoff in a eucalypt forest after 4 years of planting, at an area with dystrophic Red-Yellow Latosoland mean declivity of $43 \%$. Despite the wide range of factors that affect surface runoff, the comparison of these factors with the ones we obtained in the macaúba plantation allow us to ponder that such vegetation has features that highlight its potential for soil protection against rainfall-driven erosion, as it was shown to minimize the occurrence of surface runoff.

Nalon and Vellardi (1992) studied the correlation between gross precipitation and surface runoff in a 0.63 -ha experimental area with tree and understory vegetation at the region of Cubatão municipality, São Paulo state, southeastern Brazil. The authors observed that even small amounts of precipitation can generate surface runoff if the soil upper layer is wet or saturated, and/or if there are precipitations accumulated for at least $48 \mathrm{~h}$. This explains the results obtained in May 2013 , when $75 \%$ of precipitations generated surface runoff.

Having a slightly different aim from that of our study, Fusun et al. (2013) sought alternatives to rehabilitate areas after landslides in China, for which they tested six different plant covers. The authors evaluated soil quality, soil loss and surface runoff. Their results indicated that grasses and deciduous trees may complement one another to provide a high cover that yields a good restoration effect, which not only helps reduce surface runoff and soil erosion but also propitiates the formation of fertile islands and increases the stability of underground soils.

Complex interactions occur between plants and soil properties. Plants can improve soil properties, which in turn affect plant growth. Additionally, being considered as one of the major indicators of soil erosion, soil structure is closely related to the loss of water and soil due to the physical properties of the latter, such as high water storage capacity, bulk density and porosity (Zhang et al., 2015). On the other hand, depending on its physical properties, soils can also contribute to increase water infiltration and minimize surface runoff.

\section{CONCLUSION}

The treatment with narrow-base terrace was the one that showed the lowest volumes $(\mathrm{mm})$ of surface runoff along the twelve months of the study period. It was also the treatment that demanded the highest precipitation volume for surface runoff to occur.

The treatment with bean plants cultivated between the lines of macaúba individuals showed higher values of surface runoff at all 12 months of the study period, with a slight reduction in January and February 2013, when bean plants were more well developed.

To cultivate the macaúba palm at the declivity condition adopted in our experiment (ca. 25\%), we recommend the use of narrow-base terraces as a method to control surface runoff and prevent the consequent soil erosion.

\section{REFERENCES}

Bertoni J, Lombardi Neto F. Conservação do solo. $3^{a}$.ed. São Paulo: Ícone; 1990.

Bochet, E, Rubio, JL, Poesen, J. Modified topsoil islands within patchy Mediterranean vegetation in SE Spain. Catena.1999:38:23-44.

Costa e Silva JO. Capacidade combinatória e seleção de pessegueiro para baixa necessidade de frio hibernal [tese]. Viçosa, MG: Universidade Federal de Viçosa; 2008.

Costa CFG, Figueiredo RO, Oliveira FA, Santos IPO. Escoamento superficial em Latossolo Amarelo distrófico típico sob diferentes agroecossistemas no nordeste paraense. Revista Brasileira deEngenharia Agrícola Ambiental.2013;17(2):62-9.

Dias HCT, Sato AY,Oliveira Neto SN, Morais TC, Freire A, Bento PS. Cultivo da macaúba: ganhos ambientais em áreas de pastagens.

InformeAgropecuário.2011;32(265):52-60.

El Kateb H, Zhang HF, Zhang PC,Mosandl R. Soil erosion and surface runoff on different vegetation covers and slope gradients: a field experiment in Southern Shaanxi Province, China.Catena.2013;105:1-10.

Fernandes RP, Silva RWC, Salemi LF, Andrade TMB, Moraes JM. Geração deescoamento superficial em uma microbacia com cobertura de cana-de-açúcar e floresta ripária. Revista Ambiente \& Água.2013;8(3):178-90.

Revista Árvore. 2018;42(1):e420104 
Ferreira DF. SISVAR: a computer statistical analysis system. Ciência

Agrotecnologica.2011;35:1039-42.

Fusun S,Jinniu W, Tao L, Yan W,Haixia G,Ning W. Effects of different types of vegetation recovery on runoff and soil erosion on a Wenchuan earthquake-triggered landslide, China. Journal Soil Water Conservation.2013;68(2):138-45.

Lima, WP. Escoamento superficial, Perdas de solo e de nutrientes Em microparcelas reflorestadas com eucalipto em solos arenosos no município de São Simão, Sp.. IPEF.1988(38):5-16

Lorenzon AS, Dias HCT, Tonello KC. Escoamento superficial da água da chuva em um fragmento florestal de mata atlântica, Viçosa, MG. Revista Brasileira AgropecuáriaSustentavél. 2015; 5:50-8.

Nalon MA, Vellardi ACV. Escoamento superficial pluvial na floresta secundária das encostas da
Serra do Mar, região de Cubatão, SP. Revista Instituto Florestal.1992;4:860-6.

Penman HL. Vegetation and hydrology. London: Commonwealth Agricultural Bureau;1963.

124p.(Technical communication, 53).

Pimentel LD, Manfio CE, Motoike SY, Paes JMV, Bruckner CH.Coeficientes técnicos e custos de produção do cultivo da macaúba. Informe Agropecuário. 2011;32(265):61-9.

Silva BS, Resende M, Souza AR, Margolis E. Mobilização do solo, erosão e produtividade de milho e feijão em um Regossolo no agreste pernambucano. Pesquisa Agropecuária Brasileira.1999;34(2):299-307.

Zhang L, Wang J,Bai z. Effects of vegetation on runoff and soil erosion on reclaimed land in an opencast coal-mine dump in a loess área. Catena.2015;128:44-53. 